\title{
Psalm 26 and Proverbs: Tracing wisdom themes
}

\begin{tabular}{|c|c|}
\hline \multicolumn{2}{|c|}{$\begin{array}{l}\text { Author: } \\
\text { Annette Potgieter }{ }^{1,2}\end{array}$} \\
\hline \multicolumn{2}{|c|}{$\begin{array}{l}\text { Affiliations: } \\
{ }^{1} \text { Department Ancient } \\
\text { Languages, University of } \\
\text { Pretoria, South Africa }\end{array}$} \\
\hline \multicolumn{2}{|c|}{$\begin{array}{l}{ }^{2} \text { Department New Testament, } \\
\text { University of Pretoria, } \\
\text { South Africa }\end{array}$} \\
\hline \multicolumn{2}{|c|}{$\begin{array}{l}\text { Correspondence to: } \\
\text { Annette Potgieter }\end{array}$} \\
\hline \multicolumn{2}{|c|}{$\begin{array}{l}\text { Email: } \\
\text { annettepotgieter1@gmail. } \\
\text { com }\end{array}$} \\
\hline \multicolumn{2}{|c|}{$\begin{array}{l}\text { Postal address: } \\
22 \text { Allcock Street, Colbyn } \\
0083, \text { South Africa }\end{array}$} \\
\hline \multicolumn{2}{|c|}{$\begin{array}{l}\text { Dates: } \\
\text { Received: } 12 \text { Dec. } 2012 \\
\text { Accepted: } 28 \text { Oct. } 2013 \\
\text { Published: } 13 \text { May } 2014\end{array}$} \\
\hline \multicolumn{2}{|c|}{$\begin{array}{l}\text { How to cite this article: } \\
\text { Potgieter, A., 2014, 'Psalm } \\
26 \text { and Proverbs: Tracing } \\
\text { wisdom themes', Verbum } \\
\text { et Ecclesia } 35(1), \text { Art. \#818, } \\
7 \text { pages. http://dx.doi. } \\
\text { org/10.4102/ve.v35i1.818 }\end{array}$} \\
\hline \multicolumn{2}{|c|}{$\begin{array}{l}\text { Note: } \\
\text { Annette Potgieter is a } \\
\text { Research Associate with } \\
\text { the Department of New } \\
\text { Testament, University } \\
\text { of Pretoria. This article } \\
\text { derives from her MA thesis } \\
\text { in Ancient Cultures and } \\
\text { Languages. }\end{array}$} \\
\hline \multicolumn{2}{|c|}{$\begin{array}{l}\text { Copyright: } \\
\text { (C) 2014. The Authors. } \\
\text { Licensee: AOSIS } \\
\text { OpenJournals. This wc } \\
\text { is licensed under the } \\
\text { Creative Commons } \\
\text { Attribution License. }\end{array}$} \\
\hline \multirow{2}{*}{ Read online: } & \\
\hline & $\begin{array}{l}\text { Scan this QR } \\
\text { code with your } \\
\text { smart phone or } \\
\text { mobile device } \\
\text { to read online. }\end{array}$ \\
\hline
\end{tabular}

The discernment of Psalm 26 as a cultic psalm has prevented noticing vital connections with wisdom literature. These connections with Proverbs and other known wisdom psalms provide clues for the composition of Psalm 26 to be set in the post-exilic period. The way in which wisdom literature is used conveys the religious ethos and daily life of a community. The fact that the wisdom character of Psalm 26 has been overlooked can be viewed as one of the main reasons why Psalm 26 has been interpreted solely in a cultic setting. The sapiential influence of this psalm has been confused to only reflect the cultic aspects. The psalmist wants to live a life according to wisdom as he seeks the rewards of being close to Yahweh.

\section{Introduction}

Wisdom may be seen as a thread running through the whole fabric of the Old Testament ${ }^{1}$ (Kidner 1964:15; cf. Whybray 1965:11). Wisdom forms an integral part of the Jewish tradition and functions as a guideline to faith, an instruction manual for practices and a pillar for all commandments (Greenberg 2000:12). It can be described as the manner in which a person organises his or her life in order for it to lead to a good end (Gunkel 1998:293; cf. Martin 1995:17). Wisdom is in effect concerned with the practical as it is concerned with a wide range of skills concerning how to survive, and it even includes personal relationships ${ }^{2}$ (Whybray 1965:15). Wisdom is not a natural ability but has to be attained via learning ${ }^{3}$ (Lang 1986:15).

It is noteworthy that wisdom determines the norms of good behaviour and accordingly encompasses ethics that reflects the view of life as well as the religious ethos of a community (Human 2010:526). This religious ethos should not be isolated from its sapiential character and understood as merely depicting a cultic setting as seems to have been the case for Psalm 26. Various connections can be made between Psalm 26 and known wisdom psalms and Proverbs. These connections have been overlooked and suggest that Psalm 26 should not be confined to a cultic interpretation. An intertextual approach makes it possible to discern similar thought patterns, explore word links which are not necessarily significant in itself but significant as a collection of similar thoughts or motifs (Gosse 2008:25). This provides information on the community responsible for the text and its context as is evident from wisdom in the book of Proverbs as well as in Psalms (Gosse 2008:25). This study will regard psalms that exhibit extensive linguistic and thematic correlations with established wisdom literature as 'wisdom psalms'. ${ }^{4}$ It is not the aim of this study to engage in the debate pertaining to the classification of wisdom psalms and to categorise Psalm 26 as such, but it regards the wisdom character that psalms reflect as priority (Human 2010:524). Coincidently, there are recurrent wisdom themes and motifs in Psalm 26 of which some themes such as testing and trying, the wicked and to sit with the righteous will be explored further in this article.

\section{Typical wisdom themes in Psalm 26 and Proverbs Testing and trying}

בחנני [prove me] and [סני [test me] are typical of wisdom language because it is the desire of the wise to be deemed blameless and pure by God. Verse 2 of Psalm 26 uses language

1.Whybray (1965:11) mentions that 'the entire theological thinking of later Judaism came more or less under the sway of wisdom'. The Hebrew canon comprises the Law, the Prophets and the Writings. The most prominent works of the third part, including the Psalms, are Proverbs, Job and Ecclesiastes-Qoheleth, known as Wisdom Books (Scott 1965:xvi; cf. Whybray 1965:14). Scott (1965:xvi) refers to wisdom writings as a 'third force' in the religious and communal life of the Old Testament people.

2.It is interesting that Waltke (2008:229) understands wisdom as a social skill and, accordingly, argues that God functions as a 'unified plurality of persons in order to exercise and experience social skill'. In effect, this social skill would include kinship relationships and the communal life of Israel.

3.It is something that a person has to choose, and if a person does not have wisdom, it is the result of a decision made to fail at grasping it (Yoder 2009:258)

4.In Herman Gunkel and Joachim Bergrich's Einleitung in die Psalmen, the term 'Weisheitsdichtung' (wisdom poetry) is said to have caused more confusion than solutions in the scholarly community (Crenshaw 2001:87). The concept 'wisdom psalm' is debated since few scholars agree on which psalms should be listed as such, but the concept underlying the term is that it refers to psalms that were created in a wisdom milieu (Hurvitz 1988:41; cf. Day 1990:54; Human 2010:523). The delineation between 'pure' wisdom psalms and wisdom-related psalms is problematic (Human 2010:523-524). The 'wisdom psalms' represent what may be called the pious wing of the wisdom movement (Scott 1965:xxi). It is not the focus of this article to classify Psalm 26 as a wisdom psalm. 
associated with the smelting and refining of metals (צרופה), and it also refers to the testing of the genuineness of gold and silver by heating with fire (Clifford 2002:144). It is significant that צרופה in Psalm 26:2 also occurs in Proverbs 30:5. In the context of Proverbs 30:5, 'every word of God is refined', a statement which is contrasted to tainted human speech (Botha 2012:53). Proverbs 30:1 begins with the professing of atheism by an ignorant person, and this is complemented by references to words of lies, falsehood, the denial of Yahweh and the exploitation of the poor (Botha 2012:53). The redactors of the Psalter possibly reacted against this group of evildoers, mentioned in Proverbs 30:5, by confirming in Psalm 26 that they were evil. Again, the idea is enforced that, if wisdom is sought out, a person will find Yahweh. Yahweh's words are pure and unadulterated.

Psalm 26:2 correlates with Proverbs 17:3 מכור לזהב ובחן לבות יהוה [the crucible for silver and the furnace for gold, but the Lord tests the heart]) and Proverbs 30:5 (מגן הואלחסיםבו בל־אמרת אלוה צרופה [every word of God is flawless; he is a shield to those who take refuge in him]). The words בחן [test] and צרף [try] in Psalm 26:2 refer especially to the testing and trying of metals as seen in Proverbs 17:3 and 30:5. Proverbs 17:3 describes the process through which Yahweh 'tests' the heart as a furnace and purifies metallic ore by heating it until pure silver or gold can be extracted (Fox 2009:625; cf. Clifford 1999:164). Proverbs 17:3 is significant since it forms part of the 25 Yahweh sayings, displaying an editorial tendency in Proverbs (Weeks 1994:62). These Yahweh sayings belong together as a group and convey the idea of Yahweh's primacy as well as his righteous will (Weeks 1994:62). This implies that the editor felt the need to reinterpret material though it cannot be assumed that the material presented is 'old' wisdom (Weeks 1994:62). In this case, it is proposed that the words of Agur in Proverbs 30:5 indicate similarities to Psalm 26:2 and Proverbs 17:3, leading to the idea that it was old wisdom that had been edited by a group of editors. I posit that it is possible that Proverbs 30:1-5 is in opposition to typical wisdom. It is significant that, in the Septuagint (LXX), Proverbs 30:1 does not begin with the names of Agur and Jakeh but rather serves as an attestation of wisdom. It proclaims the importance of wisdom and says that the author was not taught wisdom by men but by God.

A crucible is used to refine metals to separate any impurities from precious metal (Clifford 1999:164). In the case of Isa 48:10 הנה צרפתיך ולא בכסף בחרתיך בכור עני [See, I have refined you, though not as silver; I have tested you in the furnace of affliction]), it is evident that smelting also implies a hard trial which will both prove the sufferers' loyalty and purify them in the process (Fox 2009:625). The concept of the crucible links to the wisdom concept that the poor or person who is suffering will be helped by Yahweh if they are righteous. This concept would fit a post-exilic period since Israel had to find a way to make sense of the event of the exile.

This idea is also echoed in Jeremiah 9:7. The community depicted in Jeremiah 9:7 is a society in which no individual is safe from the other members since the community is the epitome of falsehood and deceit (Carroll 1986:239). It is a society that does not know Yahweh (Carroll 1986:239). A wise society brings peace and prosperity to their community, unlike the community in Jeremiah 9:7. If they are to be tried and tested by Yahweh, they might be shaped into wise beings. It can thus be posited that it is no coincidence that Jeremiah 9:8 also displays words from the semantic field of piety such as בפיו [their mouths] and that people are making harmful plans in their inner parts (ציו מברבו ישים ארבו), Jr 9:7). The words 'examine' and 'test' (צרפתים ובחנתים) are also applicable to Zechariah 13:9 (Barnes 1950:231; cf. Clifford 1999:164). In this instance, it is clear that being tried and tested by Yahweh has positive results, because Yahweh will take pity on his people.

דרף צrefine] also appears in 1 Samuel 28:8 (Keil \& Delitzch 1980:350). In 1 Samuel 28:8, Saul disguises himself and approaches a woman to call up the dead Samuel, something which is prohibited in Deuteronomic law (Klein 2008:271; cf. McCarter 1980:421). The perception was that the deceased had access to information regarding divine plans (McCarter 1980:421). Saul did not benefit from this deception and his demise was inevitable. ${ }^{5}$

This type of 'testing' and 'trying' is also evident in Psalm 11:5, 17:3, 66:10 and 139:23 (Kraus1988:326; cf. Schaefer 2001:64), as well as in Psalm 37:4, a known wisdom psalm (Kroll 1987:81). These instances will thus also be investigated.

\section{Psalm 17:3}

In Psalm 17:3-5, a profession of innocence occurs (Kraus 1988:245) similar to the core theme of Psalm 26. An important part of a wise person is to be blameless and righteous; accordingly, being innocent of wrongdoing is a vital element of the path of wisdom. The petitioner is confident of his innocence, as he is aware that he is an open book to Yahweh who investigates the centre of human existence in all core thinking, reasoning, planning and doing (Kraus 1988:247; cf. Weiser 1962:181). The צחר [testing] and צרף [trying] takes place at night, indicating that humans cannot hide their thoughts from Yahweh, not even when it is dark (Kraus 1988:247). It is noteworthy that Psalm 17 also consists of both negative and positive manners of stating the petitioner's innocence (Kraus 1988:247) as is also seen in Psalm 26:3-5. Furthermore, Psalm 17 uses words such as 'lips' and 'mouth' which are reminiscent of Psalm 34 and 37. It reminds one of the emphasis that the group of redactors placed on words such as mouth, eyes and tongue since these form part of the instruments of the body that need to be mastered in order to be wise. Psalm 26 does not use these words, apart from eyes in Psalm 26:3, but it presents a similar affinity for pious wisdom also evident in Psalm 17. Both Psalm 17 and Psalm 26 display sapiential influence because innocence is emphasised as being important, as is to be tested and tried by Yahweh.

5.This woman is reminiscent of Lady Folly, the antithesis of Lady Wisdom who is the personification of wisdom. A negative situation is depicted as necromancy was perceived as a sin in ancient Israel. Saul does not benefit from this encounter and only succeeds in sealing his own doomed fate. 


\section{Psalm 139:23}

Weiser (1962:807) notes about this verse that the psalmist has found the basis for complete trust in God's omnipotence. The creator alone can guide people in the way of life as is echoed in Psalm 1 (Weiser 1962:808). Weiser (1962:808) mentions the link with Psalm 1, a known wisdom psalm, but does not mention any sapiential influence in Psalm 139:23. Briggs and Briggs (1969:231-232) ascertain that perfect verbs in 'prove me' and 'test me' were changed to imperatives with the added gloss of verse 1, 'judge me', to make the psalm suited for worship in a synagogue and also in a Christian congregation. Since this study is not primarily concerned with the genre of the psalm but interprets it as a literary creation rather than a liturgical piece, the opinion is expressed here that key wisdom language functions in this verse, something which Weiser and Briggs and Briggs are not addressing. Rather, there is a concern with purity and innocence as they are key components of walking in a wise manner. Learning methods, that is, ways of obtaining wisdom, consisted of reflecting, hearing and considering with a person's heart as it was considered to be an instrument for understanding (Shupak 2003:418). Psalm 139:23 therefore also contains wisdom elements which form a parallel to Psalm 26.

\section{Heart and kidneys}

The כליה [kidney] and בל 26:2 are also suggestive of typical wisdom language. The use of various words referring to organs of the body is significant because it functions as succinct expressions used by sages (Murphy 1998:xxiv). The meanings of melting and testing of metals are used in parallel to כליה [kidney] and לב [heart] (Ridderbos 1955:225). They (kidneys and heart) are the seats of emotions and passions as well as intellectual and moral nature and in this regard reminiscent of Jeremiah 11:20, 17:10 and 20:12 (Briggs \& Briggs 1969:231). These expressions refer to a person's inner consciousness which is also evident in Psalm 7:9, 16:7 and 9 (Rogerson \& McKay 1977:118). Rogerson and McKay (1977:118), however, interpret כליה [kidney]

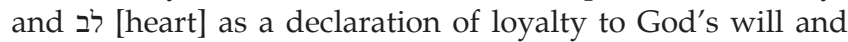
underplays the influence of wisdom. For the צדיק [righteous], the innermost feelings of the heart are proved by Yahweh (Kraus 1988:327). It is interesting that Psalm 24:4 mentions a [pure heart], which echoes the idea in Psalm 26:2 of the heart needing to be pure. Jeremiah 11:20 appeals to Yahweh and reflects an element of lament (Carroll 1986:279). There is an image of a tree in Jeremiah 11:18-20, echoing Psalm 1:3 and Jeremiah 17:8 (Carroll 1986:279). Jeremiah 17:5-11 reflects the outcry of the innocent sufferer in verse 18 (Carroll 1986:355).

\section{To sit with}

The same expression in Psalm 26:4 and 26:5, ישב ' [to sit with], is also found in Psalm 1:1 (pointed out also by Rogerson \& McKay 1977:118; cf. Barnes 1950:232; Briggs \& Briggs 1969:232; Schaefer 2001:66) and 1:4 (Kroll 1987:81). The action is emphasised in Psalm 26 as it appears in verse 4 as well as verse 5 when the psalmist denies any association with the wicked in accordance with the sitting action, which is the climax in Psalm 1 (Briggs \& Briggs 1969:232).
Psalm 1 is a late wisdom psalm. It belongs to a more didactic tradition of wisdom that establishes two ways, namely the righteous and the wicked (Craigie 2004:222). Psalm 1 describes the destinies of two opposite groups (Craigie 2004:58). The בוא [go or come] has been intentionally changed from [to walk] as it designates a reverse movement that will not move towards men whose speech and conduct is empty and false (Briggs \& Briggs 1969:232). It is an affirmation that the psalmist has remained innocent, and it serves as evidence of his piety (Barnes 1950:232). It is no coincidence that the wicked sit whilst the righteous stand or walk in Psalm 26 (Schaefer 2001:66). The psalmist affirms his innocence and severs any ties with the wicked.

The verb ישבת', seen in Psalm 26:4 [sit with]), is also found in 1 Samuel 2:8, Psalm 101:6 and 113:8 and Proverbs 31:23, and it designates the state of being a partner in a group's projects and sharing the same lifestyle (Clifford 2002:144). In the case of Proverbs 31:23, the verb ישב is used in a positive manner as Lady Wisdom's husband sits at the gates of the city, and accordingly, he is a respected man who forms part of the commercial, public and judicial activities vital to the life of the community (Fox 2009:896). It would be problematic, though, if a person chooses to sit with the wicked since this would implicate the person to partake in their plans and associate with them as is the case in Psalm 26:4.

1 Samuel 2:8: The connection with 1 Samuel 2:8 is significant because this verse is indicative of a particular ethos of a community that is reflected by the editors of Psalm 26. The idea is perpetuated that the righteous, who through the lens of Proverbs are probably the poor, will receive a chair of honour (McCarter 1980:73). In the LXX, Jeremiah 9:22 has been added but harbours the same theological viewpoint, namely that God is praised since he is concerned with the needy (Hertzberg 1964:30). 1 Samuel 2:8 contains a lengthy four-part description of Yahweh's positive action on behalf of the poor (Klein 2008:16). In the first instance, God provides military aid by breaking the bow of proud warriors (4a), an idea which is linked to Psalm 37:15 since God will break the bow of the wicked (Klein 2008:16). The song of Hannah establishes the monarchy as essentially good or God-willed since people were sceptical of the first two kings (Klein 2008:19-20). The inclusio in Samuel, with the song of Hannah opening the history of Saul and the song of David concluding his history (2 Sm 22), provides, from the perspective of the link between David and Psalm 34, a dimension of David as a theologian who is concerned with being humble and who acknowledges Yahweh's hand in his life (Botha 2008:612).

Furthermore, in 1 Samuel 2:8, it is evident that God has the power to bring people from the dead (that is, לואש) and to raise them up again (Hertzberg 1964:30). God is the creator of the world and thus does not have limited power (Hertzberg 1964:30). It is significant that 'the straits of the earth' are the great waters of the underworld ${ }^{6}$ (McCarter 1980:73). This

6 .Sheol is sometimes portrayed as underneath the surface of the earth, or sometimes, it is seen as being under the subterranean waters (Day 1990:131). 
reflects Israelite cosmogonic lore similar to Psalm 24:2. These waters were seen as swift-running waters where people were judged (McCarter 1980:73). Botha (2010:48) has shown that Psalm 24 and 89 are both connected with this verse which reiterates the strength of Yahweh as creator and his ability to change the circumstances of people. It is interesting that Lady Wisdom is closely associated with creation, and according to Murphy (1985:8), there can be no doubt about her divine origin. The idea is conveyed that humans should not act against the wicked as Yahweh is capable of ensuring justice. The righteous will benefit from Yahweh because he is the all-powerful creator who is concerned about the poor.

Jeremiah 15:17: Psalm 26:4a relates to Jeremiah 15:17 ישישתי[I never sat in the company of revelers, never made merry with them]) (Keil \& Delitzsch 1980:350). In Jeremiah 15:17, the speaker also protests to be innocent since he has steered clear of the company of merrymakers (cf. Jr 30:19; 31:4; Carroll 1986:331). The avoidance of the wicked is an aspect of a righteous person, reminiscent of Psalm 1:1. The speaker's pain in Jeremiah 15:17 is incurable, and he questions Yahweh's behaviour as the righteous suffer whilst the wicked prosper (Carroll 1986:331). The image of a wadi is used, a phenomenon leading a traveller to think that water is at hand only to discover a dried-up river-bed (Carroll 1986:331). It is a metaphor for a pious community discovering the unreliability of God as a source of water (Carroll 1986:331). It is interesting that the water echoes the use in Psalm 26:4, but in my opinion, it was not applied in the sense suggested in Jeremiah. ${ }^{7}$ Jeremiah exhibits a form of later wisdom more associated with Job and Ecclesiastes since there is a progression in wisdom thought. Consequently, this link seems to be of minor importance to the argument of this study.

In Proverbs, wisdom is portrayed as a clean-cut decision concerning lifestyle since there are those who are wicked and those who are righteous. If a righteous person is suffering, it must be because he or she has some hidden sin or some transgression of which she or he is unaware. The righteous has the hope that Yahweh will take pity on them and are assured that, although it might seem that the wicked are prospering, the road on which the wicked are travelling will eventually result in death. In the case of Psalm 26, the use of water is rather descriptive of God's almighty power and alludes to wisdom regarding creation.

\section{The wicked}

The contrast between the righteous and the wicked is a feature of wisdom literature as part of the metaphor regarding the two ways that entails moral life as two fundamental options that are in opposition (Clifford 2002:38). The opposition towards evil is a way to obtain wisdom (Kidner 1964:38). The innocence of the psalmist is perpetuated in a positive as well as in a negative manner in verses $3-5$ since the psalmist does not associate with the wicked and washes his hands in to the wadi of Egypt before Yahweh as part of Solomon's festival (Sweeney 2007:128). innocence (Schaefer 2001:64; cf. Craigie 1983:226). A human being is an ephemeral sinner and to realise these oppositions is to find true wisdom (Vawter 1975:463; cf. Day 1990:56).

The theme of the wicked occurs in Psalm 26 repeatedly since the psalmist does not want to be associated with the wicked. The same attitude toward the wicked is evident in Psalm 7:2 and 26:1 as both psalmists find refuge in Yahweh's opinion. This theme seems to be recurring in Psalm 1, 24, 34, 37 and 119, of which Psalm 34, 37 and 119 are known wisdom Psalm. The word מרעים [evildoers] appears in Psalm 26:5 as well as Psalm 37:8. In Psalm 37:8, it is connected to land that the evildoers will not inherit (Keil \& Delitzsch 1980:13).

The term found in Psalm 26:5, רשעים [wicked], is also found in Psalm 1:1, 4, 5 and 6, and there it seems to have been inspired by Proverbs 2:22 (the wicked will be removed from the land). In Psalm 1, the right conduct of God-fearing people is contrasted to that of the wicked (Weiser 1962:103). There is a strong black-and-white thinking portrayed in Psalm 1, which, according to Weiser (1962:103), originates from the claim to exclusiveness that the Yahweh cult makes. Weiser, however, overlooks the fact that Psalm 1 is based on the introduction to Proverbs. It can be argued that this type of contrast does not derive from the cult and that the contrast between the righteous and the wicked is a typical wisdom trait. In Psalm 1:6, according to Human (2010:523), it transpires that the wise way of living is in extreme contrast to the 'way of the wicked' from which Torah wisdom is absent so that the path of the wicked heads on towards self-destruction.

In Proverbs 10:20, the wicked and the righteous are identified as unwise and wise respectively (Toy 1970:212). According to Proverbs 10:20, the heart and tongue correspond to each other, and as a result of his mind, a good man's speech makes everything good in life (see Pr 10:21; Toy 1970:212). Heart and tongue symbolise a person as a communicating being, and the two nouns are parallel also in Proverbs 16:1 and Proverbs 17:20 (Clifford 1999:115). In Proverbs 10:20, the arrangement is chiastic: (a) silver, (b) tongue of the righteous, (b) heart of the wicked and (a) worthless (Clifford 1999:115). The demise of the wicked (who are called 'fools' in Pr 10:21) is echoed in Psalm 1:6b, ודרך רשעים תאבד [the way of the wicked will perish], and this is also similar to Psalm 68:3 (Hossfeld \& Zenger 2005:163). It is clear why the righteous person should avoid the company of the wicked and the fools (see Ps 26:5 and Ps 9).

The section of Psalm 26:9-11 also resonates with Psalm 139:19-22 since an examination of the thoughts of Yahweh culminates in a curse and a separation from the wicked (Schaefer 2001:64). The idea is enforced that the righteous does not only not associate with violent people ('men of blood' as also in Ps 26:9) but also hates them. It is the quest of the righteous to be innocent and have hands without blood on them. The description found of the wicked in Psalm 26:9, חטאים, [sinners], is also found in Psalm 1:1 and refers to those who deliberately choose a path that is not God's path (Rogerson \& McKay 1977:118). The term זמה, 
used for 'wickedness' in Psalm 26:10, is in turn especially associated with sexual indecency in the Old Testament, for example in Leviticus 18:17, 19:29 and 20:14; Jeremiah 13:27; Ezekiel 16:27, 22:9, 23:21 and 24:13 (Kraus 1988:328). ${ }^{8}$

There is also a connection about the terms מתי־שוא [false men], which echoes Job 11:11, and נעלמים [hidden]. They can be thought of as conjurors and sinister manipulators, that is, the condemned in Deuteronomy 18:10ff. (Kraus 1988:327). In Job 11:11, the people surveying God's work are deceitful and discerning mortals who have hidden iniquities (Habel 1985:204). God knows the truth even about secret sinners, and it is implied that even though Job is regarded as righteous, God must have seen some hidden sin and is now punishing Job (Clines 1989:264). This would fit the typical black-andwhite reasoning in Proverbs as the truly righteous will be protected by Yahweh. Day (1990:55) says that the wisdom found in Proverbs resembles a more 'orthodox' character compared to Job and Ecclesiastes which rather follow a more questioning approach.

\section{Hands}

In Psalm 26:6, the word כף [palm] is associated with the innocence of the psalmist. This is repeated in a negative sense in Psalm 26:9 as the word י [hand], associated with a palm, is ascribed to sinners. In Psalm 26:8, it is especially ascribed to the אנשי דמים [men of blood], those with blood on their hands. This is also reminiscent of Abigail's encounter with David in 1 Samuel 25 where she convinces David to remain innocent and not to shed blood because he is destined for greater things. A wise person avoids wicked plans and bloodshed.

The 'innocent palms' in Psalm 26:6 (בנקיון כפי) can also be found in Psalm 24:4 (נקי כפים [clean palms]). In the context of Psalm 24 and Proverbs, such an innocent person will receive a blessing as well as justice from God (Gosse 2008:66; cf. Botha 2010:47). In a sapiential sense, it is indicative of righteousness since a wise person is without blame. In antiquity, the cultic washing of hands ${ }^{9}$ would have been a well-known practice associated with the temple as seen in Deuteronomy 21:6 and Psalm 73:1310 (Weiser 1962:244; cf. Craigie 1983:226). Clean hands are required for a worshipper at the temple, and this ritual would take place at the entrance of the temple as is also seems to be the case in Psalm 24:4 (Craigie 1983:226). It is noteworthy that clean hands symbolised the inner cleansing of the heart and mind since this verse links up with Psalm 26:2 as well as with Psalm 24:4 (Craigie 1983:226). Weiser and Craigie do not link clean hands to sapiential influence. However, such a link is viable because cleanliness is integral to a wise living that consists of being blameless. The link with Psalm 73 is also supportive of this argument since Clifford (2002:26) indicates that Psalm 73 is a non-cultic meditation, exhibiting the influence of wisdom. Clifford

8.It also has a clear connection with wisdom as can be seen from its occurrence in Psalms 119:150 and Proverbs 10:23; 21:27 and 24:9.

9.The act of washing hands is reminiscent of the purity that is required of priests as seen in Exodus 30:17 as the priests have to wash their hands before they enter the temple (Ridderbos 1955:227); see also Deuteronomy 21:6-7 (Barnes 1950:233; cf. Kraus 1988:327).

10.Cf. Ridderbos (1955:227) and Kraus (1988:327)
(2002:26) in turn does interpret Psalm 26 as pertaining to a cultic setting, but this motif is reverberated in Proverbs 1:11 and 6:17 as well as in Psalm 24, a known wisdom psalm.

According to Proverbs 6:17, יקנ־םד [hands] that shed [innocent blood] is a thing that Yahweh hates (Botha 2010:47). Proverbs 6:16-19 forms a list of seven hateful things of which five is associated with body organs (Toy 1970:127; cf. Clifford 1999:77), that is, typical wisdom expressions. The expression 'haughty eyes' characterises Israel's proud and oppressive enemies whom Yahweh will bring down as can also be seen in Isaiah 2:11-17 and 10:33 and in Job 21:22 and 38:15 (Toy 1970:128). Furthermore, the phrase 'haughty eyes' occurs in the prayer of Psalm 18:28 and also Psalm 131:1: 'Yahweh, my eyes are not haughty'. The words in Sirach 23:4, 'O Lord do not give me haughty eyes', links to the phrase 'lying tongue' in Psalm 12:1, 21:6, 26:28 and 109:2. In the final verse of this passage, speech as a form of false witness is also used. The sages thus emphasise the importance of words as human expression (Clifford 1999:77).

Indirectly, these verses sketch a portrait of Yahweh as the kind of God who cannot accommodate such a deep-seated malice in human beings (Clifford 1999:77). Moreover, the expression 'haughty eyes' echoes Isaiah 10:12 since the Assyrian king has overstepped his boundaries through his pride against Yahweh (Van Leeuwen 1990:121). It is remarkable that, in Isaiah 10:13-14, the king prides himself on being wise; an attribute that should be associated with Yahweh is claimed by the king of Assur. The demise of the king is inevitable.

In Psalm 26:3, the psalmist only has God's דסח [goodness or kindness] before his eyes. The psalmist intends to live wisely. 'Clean hands', serving as evidence of blamelessness, is also found in Isaiah 1:16 (Kraus 1988:327). It is used in particular to argue that all wickedness must be removed before the eyes of God.

\section{Purity}

Clifford (2002:142) uses Psalm 26:6-8 as explicatory of the genre of Psalm 26. The descriptions of 'hand washing', 'going around the altar' and 'joining in liturgical song' are not viewed as mere metaphors but as reflective of temple realities. Verse 6 bears similarities to texts that describe procedures through which falsely accused people or cases without substantial evidence could go to a shrine or temple to seek a verdict from God by means of an oracle, a test or the lot, such as 1 Kings 8:31-32, Deuteronomy 17:8, Exodus 22:6-8 and Numbers 5:11 (Mays 1994:128; cf. Kraus 1988:326). Craigie (1983:225) supports this notion since he motivates that verse 2 presents a prayer to be judged as a precondition of entering the temple. It would be suicide for sinners or evildoers to enter God's house without purification because God would annihilate them, as is seen in Psalm 5:7. Accordingly, the psalmist prays for purification whilst affirming his integrity (Craigie 1983:226; cf. Schaefer 2001:65). This verse is similar to Deuteronomy 26:15, Jeremiah 25:30 and Zechariah 2:711 (Briggs \& Briggs 1969:236).

11.The context of Zechariah 2:17 pertains to the exile, and disassociation with Babylon as purity is important. Wisdom would have played a vital part in Israel's search for their identity after the exile. Consequently, purity is part of being blameless and just before God. 
Bellinger (1989:580) is also oblivious to the typical wisdom language of the psalm and solely interprets it in the context of a temple ordeal in which testing and trying represent the worshipper's innocence. Clifford (2002:142) says that priestly law permeates Psalm 26 with the symbolic act of purification, which entails a death threat if the Aaronid priests failed to perform their duties. He ascribes the prayer's origin to priestly circles. However, it has been mentioned that David is an important figure in Psalm 26, and he may be represented as performing the cultic rites ascribed to the priests. In Psalm 18, which was taken up in 2 Samuel 22 as the concluding song of David, clean hands are described as the quality which prompted Yahweh to intervene on his behalf (cf. Ps 18:21 and Ps 24). It is my opinion that purity in Psalm 26 denotes a righteous and just life before Yahweh but that it is not confined to a cultic genre and should not be narrowly interpreted as such. Psalm 26 rather resembles a meditation. The fact that 'hands that shed innocent blood' are mentioned in Proverbs 6:17 as one of the seven things that Yahweh hates is proof enough that the motif also has sapiential connections.

\section{Bribery}

This theme is closely connected to the theme of the wicked. Righteous persons do not partake in shady deals since they know that the result can only be a path of death. The word שחד can mean 'bribe' or 'gift', and in the case of the latter meaning, it is reminiscent of a gift offered to a judge to obtain an unjust sentence (Barnes 1950:235). It is well-known in wisdom poetry (see for example Job 15:34; Pr 6:35; 17:8, 23 and 21:14).

Briggs and Briggs (1969:234) argue that verse 10 probably refers to criminals who bribe and not to judges or rulers who accept bribes. It is similar to situations described in 2 Kings 13:8, Proverbs 6:35, Exodus 23:8 and Deuteronomy 10:17 (Barnes 1950:235). The instance of Proverbs 6:35 is particularly curious since it describes the context of hungerdriven theft (Clifford 1999:80). It resembles the typical blackand-white reasoning seen in Proverbs because there is no consideration for the circumstances of the thief. People in poverty must live righteous since Yahweh will take pity on them and protect them. No bribery can ever be tolerated. In Psalm 26:9, the word [gather], which implies the collecting of something, for example fruit, conveys the notion that they who truly love God must desire to be in the community of righteous people, no matter how poor or humble, and they are never to be with sinners (Barnes 1950:234-235).

\section{Conclusion}

It is evident that wisdom is intricately woven into the fabric of Psalm 26. The various links support the suggestion that the interpretation of Psalm 26 should not be confined to that of a cultic psalm. There are close links, especially to Proverbs. The core part of Psalm 26, namely verse 2, is connected to both Proverbs 17:3 and 30:5, adding to the argument that Psalm 26 was part of redactional activity in reaction to Proverbs 30:5. It seems that this redactional activity should be ascribed to the Persian period since the links are to texts of a similar era.
Psalm 26 was probably composed as a finely balanced unity, but it also reflects the intricate hand of a group of wisdominfluenced editors who were at work in other psalms because a particular way of living is postulated. These editors valued wisdom as a righteous way of living. This righteous way of living entails that a person does not associate ('sit', see also Ps 1:1) with the wicked but instead keep his or her hands clean from any wickedness and 'walk' or stand in uprightness. It is important to 'walk' on the way of Yahweh with 'integrity' (תם, see Ps 26:1 and 11; also see Ps 25:21; 37:37; 101:2 and Pr 2:7; 10:9; 29; 13:6; 19:1; 20:7; 28:6 and 29:10) and to live a life striving to be close to Yahweh. This wisdom also concerns a righteous lifestyle imitating David, a figure who became prominent after the exile since he served as the symbol of Yahweh's restoration for Israel. The ethos of David as a person to be looked up to also permeates this psalm. The love of Yahweh's house is a typical motif of this ethos, and in my view, the idea of piety is the most prominent feature of the psalm. Consequently, this psalm should not be interpreted within a cultic setting, but the cultic language must be interpreted according to the ideals associated with David. It is a core idea of this community that a person must continue acting righteously because the wicked that seems to be thriving will be dealt with by Yahweh. The links to Proverbs make this aspect clear as various texts in Proverbs allude to the theology that the wicked will have an untimely demise and will face Yahweh's judgement. It is also not the task of the righteous or wise person to seek out revenge since Yahweh will take care of the wicked.

\section{Acknowledgements Competing interests}

The author declares that she has no financial or personal relationship(s) that may have inappropriately influenced her in writing this article.

\section{References}

Barnes, A., 1950, Psalms: Notes on the Old Testament, Baker, Grand Rapids. Bellinger, W.H., 1989, 'Psalm 26', Review and Expositor 86(4), 577-582.

Botha, P.J., 2008, 'Annotated history: The implications of reading Psalm 34 in conjunction with 1 Samuel 21-26 and vice versa', Old Testament Essays 21(3), 593-617.

Botha, P.J., 2010, 'A world firmly established on water: The wisdom foundations of Psalm 24:1-2', in S. Fischer \& M. Grohmann (eds.), Weisheit und Schöpfung, pp. 43-58, Peter Lang, Frankfurt.

Botha, P.J., 2012, 'Pride and suffering of the poor in the Persian period: Psalm 12 in its post-exilic context', Old Testament Essays 25, 40-56.

Briggs, C.A. \& Briggs, E.M., 1969, The international critical commentary on the Book of Psalms, vol. 1, T \& T Clark, Edinbugh.

Carroll, R.P., 1986, Jeremiah, SCM, London.

Clifford, R.J., 1999, Proverbs: A commentary, Westminster John Knox, Louisville. Clifford, R.J., 2002, Psalms 1-72, Abingdon, Nashville.

Clines, D.J.A., 1989, Job 1-20, Word, Dallas. (Word Biblical Commentary, vol. 17).

Craigie, P.C., 1983, Psalms 1-50, Word, Waco. (Word Biblical Commentary, vol. 19).

Craigie, P.C., 2004, Psalms 1-50, 2nd edn., Thomas Nelson, Nashville. (Word Biblical Commentary, vol. 19).

Crenshaw, J.L., 2001, The Psalms: An introduction, Eerdmans, Grand Rapids.

Day, J., 1990, Psalms, JSOT, Sheffield.

Fox, M.V., 2009, Proverbs 10-31, Yale University, New Haven. (The Anchor Yale Bible, vol. 18B).

Gosse, B., 2008, L'influence du livre des Proverbes sur les redactions bibliques à l'époque Perse, Supplément 14 à Transeuphratène, Gabalda, Paris. 
Greenberg, B., 2000, 'We call it the learning tradition', The Living Pulpit, 12-13. Gunkel, H., 1998, An introduction to the Psalms, Mercer University, Macon.

Habel, N.C., 1985, Job, SCM, London.

Hertzberg, H.W., 1964, 1 \& 2 Samuel, SCM, London.

Hossfeld, F. \& Zenger, E., 2005, Psalms 2, transl. L.M. Maloney, Fortress, Minneapolis.

Human, D.J., 2010, 'Ethical perspectives from the Sîrē hama'alôt Psalm 127', in E. Zenger (ed.), The composition of the Book of Psalms, pp. 523-535, Peeters, Leuven.

Hurvitz, A., 1988, 'Wisdom vocabulary in the Hebrew psalter: A contribution to the study of "Wisdom Psalms"', Vetus Testamentum 38(1), 41-51.

Keil, C.F. \& Delitzsch, F., 1980, Psalms, transl. J. Martin, Eerdmans, Grand Rapids. (Commentary on the Old Testament in Ten Volumes, vol.5).

Kidner, D., 1964, The proverbs, Intervarsity, London.

Klein, R.W., 2008, 1 Samuel, Thomas Nelson, Nashville. (Word Biblical Commentary).

Kroll, W.M., 1987, Psalms: The poetry of Israel, University Press of America, Lanham.

Kraus, H.-J., 1988, Psalms 1-59, transl. H.C. Oswald, Augsburg, Minneapolis.

Lang, B., 1986, Wisdom and the Book of Proverbs: An Israelite Goddess redefined, Pilgrim, New York.

Mays, J.L., 1994, Psalms, John Knox, Louisville. (Interpretation).

Martin, J.D., 1995, Proverbs, Sheffield Academic Press, Sheffield.

McCarter, P.K., 1980, 1 Samuel, Doubleday, New York. (The Anchor Bible). PMid: 6245178

Murphy, R.E., 1985, 'Wisdom and creation', Journal of Biblical Literature 104(1), 3-11. http://dx.doi.org/10.2307/3260589
Murphy, R.E., 1998, Proverbs, Thomas Nelson, Nashville. (Word Biblical Commentary, vol. 22).

Ridderbos, J., 1955, De Psalmen, J.H. Kok, Kampen.

Rogerson, J.W. \& McKay, J.W., 1977, Psalms 1-50, Cambridge University Press, Cambridge.

Schaefer, K., 2001, Psalms, The Liturgical Press, Collegeville.

Scott, R.B.Y., 1965, Proverbs and Ecclesiastes, Doubleday, New York. (The Anchor Bible).

Shupak, N., 2003, 'Learning methods in Ancient Israel', Vetus Testamentum 53(3), 416-426. http://dx.doi.org/10.1163/156853303768266380

Sweeney, M.A., 2007, 1 \& 2 Kings, John Knox, Westminster.

Toy, C.H., 1970, Proverbs, T \& T Clark, Edinburgh. (A Critical and Exegetical Commentary)

Van Leeuwen, R.C., 1990, 'Liminality and worldview in Proverbs 1-9', Semeia 50, 111-144.

Vawter, B.C.M., 1975, 'Postexilic prayer and hope', Catholic Biblical Quarterly 37, 460-470.

Waltke, B.K., 2008, 'Righteousness in Proverbs', Westminster Theological Journal 70(2), 225-237.

Weeks, S, 1994, Early Israelite wisdom, Oxford University Press, Oxford.

Weiser, A., 1962, The Psalms, SCM, London. PMCid:PMC1057806

Whybray, R.N., 1965, Wisdom in Proverbs: The concept of wisdom in Proverbs 1-9, SCM, London.

Yoder, C.R., 2009, 'On the threshold of Kingship: A study of Agur (Proverbs 30)', Interpretation 63(3), 254-263. http://dx.doi.org/10.1177/002096430906300304 